\title{
Analysis of orthopedic treatment of skeletal Class IIImalocclusion with Rapid Palatal Expansion and Face Mask therapy
}

Análise do tratamento ortopédico da má oclusão de Classe III com Expansão Rápida Palatal e terapia de Máscara Facial

Ana de Lourdes SÁ DE LIRA", Igo Rafael Costa ARAÚJO²

1 - Universidade Estadual do Piauí - UESPI - School of Dentistry - Department of Pediatric Dentistry and Orthodontics - Area of Integrated Clinic - Parnaíba - PI - Brazil.

2 - Universidade Federal do Piauí - UFPI - School of Dentistry - Department of Orthodontics - Area of Integrated Clinic - Teresina, PI, Brazil.

\begin{abstract}
Aim: To demonstrate the main effects on maxillary and facial profile after treatment with expansion and face mask therapy in patients pattern III Class III. Material and Method: A cross-sectional study of maxillary expansion and reverse traction performed in 4 patients with maxillary deficiency, in the pre-peak pubertal growth stage and in the mixed dentition, with cephalograms before and after treatment, using angular measurements (SNA, SNENA, ANL and 1NA) and linear (S'-ENA, S'-A, 1-NA, OVERJET, S-LS and S-LI) and plot overlays. Results: Improvement in overjet was observed, going from negative to positive in all cases treated with incisor uncrossing, although it was not statistically significant. The upper and lower labial posture with respect to the base of the nose and the ment improved significantly, represented by the measurements S-LS and S-LI, with a change from the concave profile to slightly convex. Conclusion: Class III malocclusion with maxillary deficiency treated with rapid maxillary disjunction and reverse traction with facial mask was effective in both groups, with maxillary protraction and shifting in the concave to slightly convex profile.
\end{abstract}

\section{KEYWORDS}

Facial Mask; Rapid maxillary expansion; Class III.

\section{RESUIMO}

Objetivo: Demonstrar principais efeitos no maxilar e no perfil facial ocorridos após tratamento com expansão e tração reversa maxilar em pacientes Padrão III Classe III. Material e Método: Estudo transversal da expansão maxilar e tração reversa realizado em 4 pacientes com deficiência maxilar, em fase de pré-pico de crescimento puberal e na dentadura mista, com telerradiografias antes e após o tratamento, utilizandose medidas angulares (SNA, SNENA, ANL e 1NA) e lineares (S'-ENA, S'-A, 1-NA, OVERJET, S-LS e S-LI) e sobreposições de traçados. Resultados: Foi observada melhora na sobressaliência, passando de valor negativo para positivo em todos os casos tratados com o descruzamento dos incisivos, apesar de não ter sido significativo estatisticamente. A postura labial superior e inferior em relação à base do nariz e mento melhorou significativamente, representada pelas medidas S-LS e S-LI, com mudança do perfil côncavo para levemente convexo. Conclusão: A má oclusão de Classe III com deficiência maxilar tratada com disjunção rápida da maxila e tração reversa com máscara facial foi eficaz nos dois grupos, observando-se protração maxilar e mudança no perfil de côncavo para levemente convexo.

\section{PALAVRAS-CHAVE}

Máscara facial; Expansão rápida da maxila; Classe III. 


\section{INTRODUCTION}

$\mathrm{T}$ he pattern III of facial growth has genetic influences, which contribute to the determination of greater or lesser sagittal discrepancy of the bone bases. The findings of the clinical examination and facial profile analysis should be complemented by cephalometric analyzes, study models and photographs [1].

Due to its unfavorable facial characteristics, it is ideal that the diagnosis and interception be precocious to obtain greater orthopedic effects and smaller dental alterations $[2,3]$. For this reason, the best time to start treatment would be in the deciduous dentition, from the age of five or at the beginning of the mixed dentition, coinciding with the eruption of the upper central incisors $[1,4,5,7]$.

The long-term success of treatment of Class III malocclusion by maxillary expansion and protraction therapy is associated with its onset prior to the pubertal growth spurt. The expansion mechanics is in opposition to the tendency of maxillary contraction during protraction [2-6].

However, this therapeutic approach has a precise indication for those patients who are deficient in the development of the middle third of the face. Due to the difficulty in predicting how maxillomandibular growth will occur in cases where the intervention is performed before the end of growth, there is the possibility that in the adult phase orthosurgical treatment may be necessary [7].

The reverse traction of the maxilla presents some limitations such as: facial anchorage device, low patient acceptance, time of use from 12 to 16 hours per day. Despite its proven efficacy, the genetic growth factor may lead to recurrence of the pattern $[5,6]$. With this therapy, maxillary displacement in the anterior direction, mandibular plane rotation clockwise, anterior displacement of the upper dental arch, lingual inclination of the lower incisors, anteroinferior facial height increase and facial convexity increase [1].

It is justified to carry out this research to investigate if the result of the changes of the middle third of the face and in the facial esthetics is identical when the maxillary traction is executed during or after the palatal disjunction.

The objective of this research was to demonstrate the main effects on maxillary and facial profile after treatment with expansion and face mask therapy in patients pattern III Class III.

\section{METHOD}

This was a cross-sectional, quantitative, interventional study of a non-randomized clinical trial type previously approved by the Ethics and Research Committee (ERC) of the State University of Piauí with number 2.043.467 carried out in the orthodontic clinic of the orthodontics specialization course Federal University of Piauí (FUPI).

The inclusion criteria of the referred patients were:

1) Pattern III of face with maxillary deficiency, evaluated by the nasogenian sulcus and deficiency of the malar region;

2) Pattern III of skeletal growth, determined by measurement Witts $<0 \mathrm{~mm}$ and ANB $\leq 0$ degrees [4];

3) stage of deciduous or mixed dentures;

4) anterior crossbite or end-to-end relationship, associated or not with posterior crossbite;

5) absence of previous orthodontic treatment; 
6) absence of congenital alterations and / or other facial deformities. Those who did not present the characteristics mentioned in the inclusion criteria were excluded from the sample, or those whose parents or guardians did not authorize participation in the research.

A clinical examination was performed to diagnose the previous cross-bite in the assisted children, with spontaneous demand, according to inclusion criteria, from June 2017 to May 2018 after signing the Free and Informed Consent Term (FICT) and the Term of Assent Free and Clarified (TAFC).

The skeletal age of the patients was evaluated using the maturation method of the cervical vertebrae. All patients selected for this study presented before stage 3 , that is, before the peak of the pubertal growth spurt $[8,9]$.

Patients before treatment were divided into two groups, randomly selected, until the same amount was obtained in both groups. In group 1 (cases 1 and 3), rapid maxillary expansion (RME) was performed before reverse maxillary traction (RMT), and in group 2 (cases 2 and 4) it was performed simultaneously.

For the study of the induced skeletal and tegumentary alterations, lateral cephalograms of patients treated in the orthodontic specialization course, aged between 8 and 11 years, in the mixed and permanent dentition, were used. For the treatment were used modified Haas [10] expander for RME and Petit $[2,11]$ facial mask for RMT for a period of approximately 12 months. Radiographs were obtained twice: before and at the end of treatment (approximately after 12 months).

The Hass expansion activation protocol was $1 / 4$ turn in the morning and $1 / 4$ turn at night for a period of 15 days or until the diastema between the incisors was reached (clinical evidence of disjunction) [10]. Patients were instructed on oral hygiene and eating habits during treatment.

Interception was initiated with RME to correct posterior crossbite, if present, or as an anchoring preparation to counteract the tendency of upper arch to narrow during the RMT phase.

The facial mask selected for the RMT was Petit's mask $[2,11]$, with elastic force applied $3 / 4$ of an inch in the welded hooks on the vestibular face of the strips of the breaker extending to the canines, to the hooks in the facial mask, at the level of the labial commissure. The force was gradually increased with the course of the treatment, starting with 200-300 gf on each side, in the first two months and thereafter, force of 400-600 gf on each side, until obtaining horizontal overjet, at least $2 \mathrm{~mm}$, measured from the palatal of the maxillary incisors in relation to the inferior vestibular face (considered a normal pattern according to Steiner's cephalometric analysis) [11]. All patients were instructed to use the face mask for 12 hours a day. Monthly, the children were photographed and examined for control of interceptive treatment, oral conditions and adjustment of the device, if necessary, until malocclusion was corrected. The circuit breaker remained installed until 4 months after the end of the RMT as retention.

To measure the skeletal and tegumentary alterations, lateral cephalograms obtained in two different times were used: T1- beginning of the treatment, before the installation of the apparatus; T2- end of treatment.

Cephalograms were drawn on the cephalograms manually by the same examiner, previously calibrated, using 0.7 black graphite pencil. Angular measurements were added to the nearest value, when there was a decimal fraction. The comparative analysis between the two groups was performed by means of angular and linear measurements obtained, matching the two times ( $\mathrm{T} 1$ and $\mathrm{T} 2$ ). 
The error of the method was obtained by four randomly chosen radiographs, whose tracings were obtained by the same investigator on two occasions separated by at least two months. The Dahlberg formula [12] was used: $\mathrm{ME}=\backslash / \sum \mathrm{d} 2 / 2 \mathrm{n}$, where $\mathrm{n}$ is the number of duplicate measurements. The random errors varied between 0.26 and 0.92 $\mathrm{mm}$ for linear measurements and between 0.28 and 0.91 for angles.

Dental, skeletal and tegumentary alterations were measured using cephalometric measurements. For skeletal analysis, angular (SNA, SNENA) and linear measurements (S'ENA and S'-A); (S-LS and S-LI) (Figure 1), totalizing 4 angular and 6 linear measurements (Figure 1).

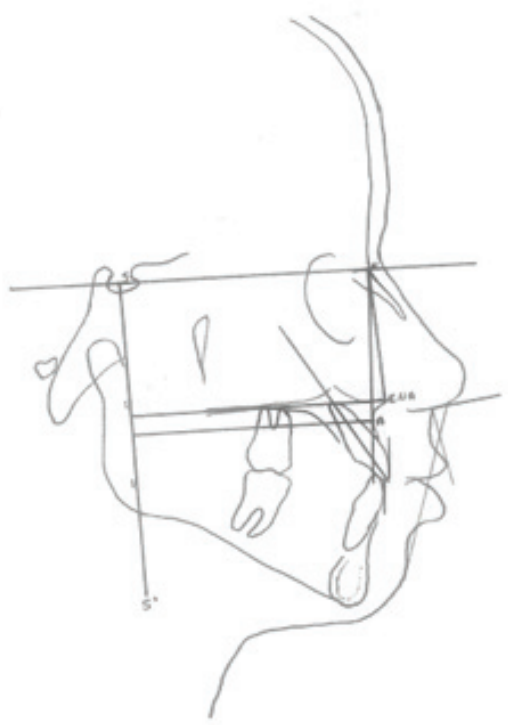

Figure 1- Cephalometric measures used in the research.

Total and partial overlaps were performed between $\mathrm{T} 1$ and $\mathrm{T} 2$, with total overlap in the SN line with $\mathrm{N}$-register (and in the contour of the facial profile) (Figure 2); The partial ones were three: maxillary overlap with PTM recording (verification of anteroposterior changes in maxillary position), (Figure 3), superposition of the maxilla over the border of the anterior border of the zygomatic process (Key Ridge) (Figure 4) and overlapping of the maxilla over the palatal plane with ENA registration (verification of dental changes (Figure 5) [11].

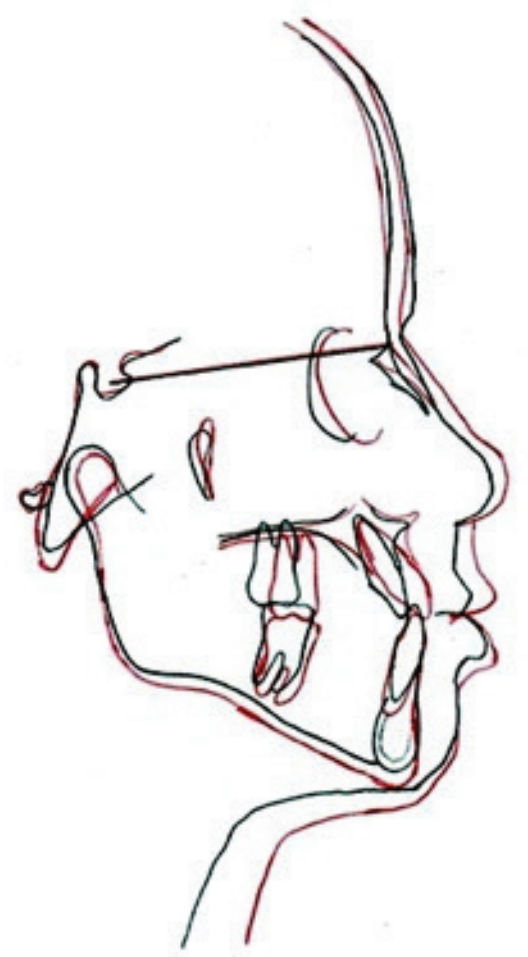

Figure 2 - Superposition between T1 (black line) and T2 (red line) to verify changes in facial profile.

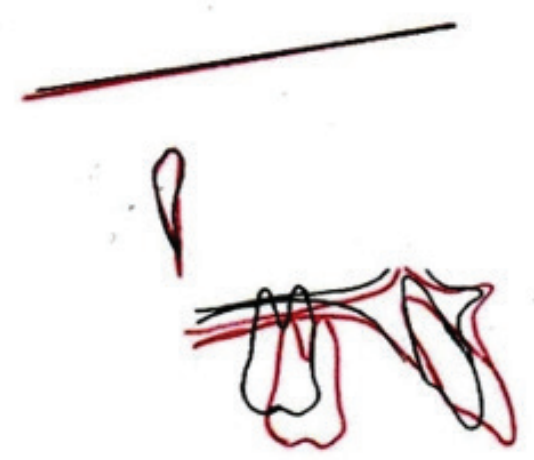

Figure 3 - Superposition of the maxilla with PTM registration between T1 (black line) and T2 (red line) to verify the anteroposterior changes of the maxilla. 


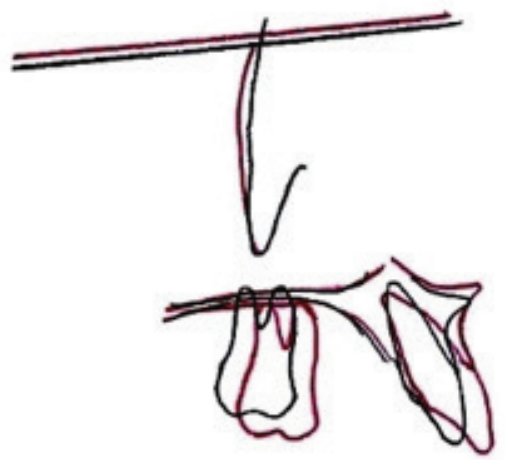

Figure 4 - Superposition of the maxilla on Key Ridge for evaluation of vertical maxillary changes between T1 (black line) and T2 (red line).

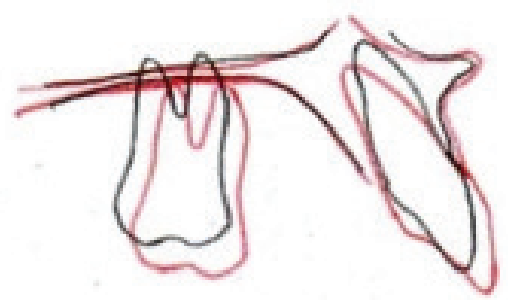

Figure $\mathbf{5}$ - Superposition of the maxilla over the palatal plane with ENA (verification of tooth modifications) between T1 (black line) and T2 (red line).

Regarding the statistical treatment, the SPSS program, version 21 [12], was used to perform comparative analyzes between the groups (T1 and T2). The Mann-Whitney non-parametric test was used to test the significance level of $5 \%(\mathrm{p}<0.05)$ and descriptive data of the measurements of each patient were obtained as well as mean and standard deviation.

\section{RESULTS}

During the year of the study, 8 patients met the inclusion criterion, but 2 of them started the treatment, but did not continue and 2 did not start. The four patients treated had the mean ad standard deviation of age of 5.3 $\pm 0.5,3$ of whom were male (cases 1,2 and 4) and presented the measurement Witts $(\mathrm{mm})$ $-1.5,-1.7$ and -1.6 respectively in $\mathrm{T} 1$ and 0.5 ,
0.4 and 0.3 in T2. The female gender (case 3) showed $-0.8 \mathrm{~mm}$ in $\mathrm{T} 1$ and $0.5 \mathrm{~mm}$ in $\mathrm{T} 2$. The angular and linear measurements of the 4 patients at T1 and T2 times were set out in Tables 1 and 2, respectively. Mean, difference between measurements between $\mathrm{T} 1$ and $\mathrm{T} 2$ and significance were shown in Table 3.

Table 1 - Angular and linear measurements of the 4 patients in $\mathrm{T} 1$

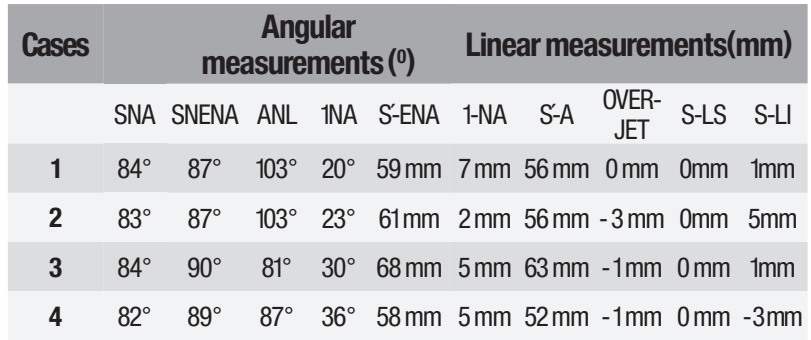

Table 2 - Angular and linear measurements of the 4 patients in $\mathrm{T} 2$

\begin{tabular}{|c|c|c|c|c|c|c|c|c|c|}
\hline \multirow[t]{2}{*}{ Cases } & & \multicolumn{4}{|c|}{$\begin{array}{c}\text { Angular } \\
\text { measurements }\left({ }^{0}\right)\end{array}$} & \multicolumn{4}{|c|}{ Linear measurements(mm) } \\
\hline & SNA & SNENA & ANL & $1 N A$ & S-ENA & 1-NA S-A & $\begin{array}{l}\text { OVER- } \\
\text { JET }\end{array}$ & S-LS & S-LI \\
\hline 1 & $88^{\circ}$ & $91^{\circ}$ & $93^{\circ}$ & $21^{\circ}$ & $65 \mathrm{~mm}$ & $4 \mathrm{~mm} 62 \mathrm{~mm}$ & $6 \mathrm{~mm}$ & $2 \mathrm{~mm}$ & $2 \mathrm{~mm}$ \\
\hline 2 & $88^{\circ}$ & $93^{\circ}$ & $90^{\circ}$ & $30^{\circ}$ & $64 \mathrm{~mm}$ & $4 \mathrm{~mm} 60 \mathrm{~mm}$ & $1 \mathrm{~mm}$ & $3 \mathrm{~mm}$ & $6 \mathrm{~mm}$ \\
\hline 3 & $86^{\circ}$ & $90^{\circ}$ & $79^{\circ}$ & $29^{\circ}$ & $71 \mathrm{~mm}$ & $6 \mathrm{~mm} 66 \mathrm{~mm}$ & $4 \mathrm{~mm}$ & $1 \mathrm{~mm}$ & $1 \mathrm{~mm}$ \\
\hline 4 & $84^{\circ}$ & $90^{\circ}$ & $80^{\circ}$ & $41^{\circ}$ & $60 \mathrm{~mm}$ & $7 \mathrm{~mm} 55 \mathrm{~mm}$ & $1 \mathrm{~mm}$ & $1 \mathrm{~mm}$ & $2 \mathrm{~mm}$ \\
\hline
\end{tabular}

Table 3 - Mean, standard deviation of the measurements, difference between T1 and T2 and result of the non-parametric Mann-Whitney test

\begin{tabular}{|c|ccccc|}
$\begin{array}{c}\text { Measure- } \\
\text { ments }\end{array}$ & $\begin{array}{c}\text { T1 } \\
\text { Average } \\
\text { SD }\end{array}$ & $\begin{array}{c}\text { T2 } \\
\text { Average } \\
\text { SD }\end{array}$ & Diference & P valor & $\begin{array}{c}\text { Signifi- } \\
\text { cance }\end{array}$ \\
\hline SNA( $(0)$ & $83.25 \pm 0.95$ & $86.5 \pm 1.9$ & 3.25 & 0.04 & $*$ \\
\hline SNENA(0) & $88.25 \pm 1.5$ & $91 \pm 1.41$ & 2.75 & 0.04 & $*$ \\
\hline ANL( $(0)$ & $93.5 \pm 11.23$ & $85.5 \pm 7.04$ & -8 & 0.24 & n.s \\
\hline 1NA(0) & $27.25 \pm 7.18$ & $30.25 \pm 8.22$ & 3 & 0.66 & n.s \\
\hline S-ENA(mm) & $61.5 \pm 4.50$ & $64.75 \pm 4.11$ & 3.25 & 0.25 & n.s \\
\hline 1-NA(mm) & $4.75 \pm 2.06$ & $5.25 \pm 1.5$ & 0.5 & 0.77 & n.s \\
\hline S-A(mm) & $56.75 \pm 4.57$ & $60.75 \pm 4.57$ & 4 & 0.05 & $*$ \\
\hline Overjet(mm) & $-1.25 \pm 1.25$ & $3.0 \pm 2.44$ & 1.75 & 0.29 & n.s \\
\hline S-LS(mm) & $0-$ & $1.75 \pm 0.95$ & 1.75 & 0.02 & $*$ \\
\hline S-L(mm) & $1 \pm 1$ & $2.75 \pm 2.21$ & 1.75 & 0.01 & $*$ \\
\hline & & & & & \\
\hline
\end{tabular}

${ }^{(*)} \mathrm{O}$ significance at $5 \%$; $\left(^{* *}\right) \mathrm{O}$ significance at $1 \%$. (n.s) $\mathrm{O}$ not significant 


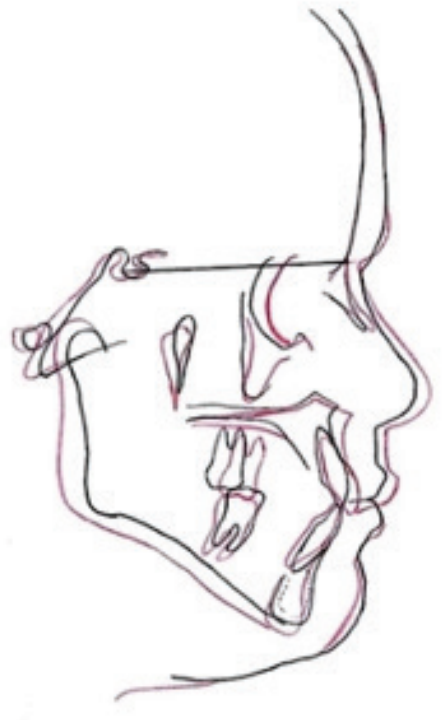

Figure 6 - Superposition T1 (black line) X T2 (red line) of group 1.

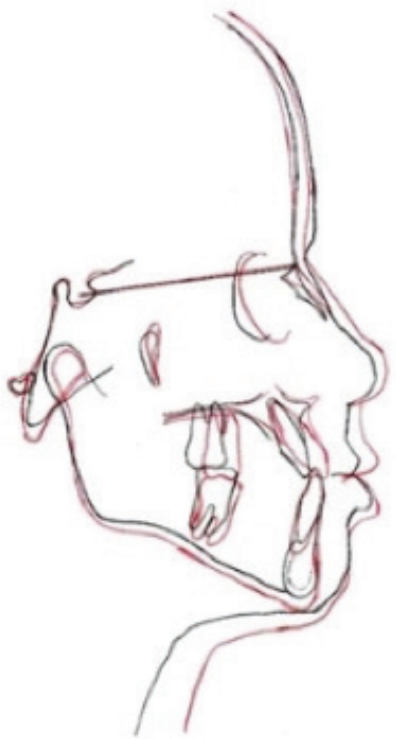

Figure 7 - Superposition T1 (black line) X T2 (red line) of group 2.

\section{DISCUSSION}

The early treatment of Class III malocclusion due to maxillary atresia is directly related to the level of patient cooperation, which is a decisive factor for success, and it is usually difficult for them to adapt to the use of the facial mask $[13,14]$. In addition, this malocclusion affects dentofacial appearance and harmony, causing psychological problems for children, and may develop negative attitudes of self-depreciation and low selfesteem [15-18].

The expansion mechanics opposes the tendency of maxillary contraction during protraction. However, this therapeutic approach has a precise indication for those patients who are deficient in the development of the middle third of the face, with or without Class III malocclusion [1-7,14-16,18].

After the diagnosis of bone base deficiency, with retracted maxilla, regardless of the presence of crossbite, it is indicated the placement of an expander apparatus with the intention of stimulating growth sites and sutures, such as, the frontomaxillary, the nasomaxillary and the zygomatic -jaw. The disjunction of the sutures facilitates orthopedic work, as well as normal maxillary growth, which has a downward and forward shift [14].

Maxillary protraction is considered the best therapy in patients in the growth phase. The magnitude, vector direction of the force applied, and the number of hours per day are extremely important for the success of RMT therapy. The direction of the force vector is forward and down, varying the degree of inclination, between $20^{\circ}$ to $45^{\circ}$ with respect to the occlusal plane, with $80 \mathrm{gf}$ to $800 \mathrm{gf}$ for 10 hours per day or for full time [1-7,14-16,18].

In the present study, the effects of RME with RMT were evident in both group 1 and group 2. Regarding the SNA measure, which expresses the degree of protrusion or retrusion of the maxilla relative to the base of the skull [11], between $\mathrm{T} 1$ and $\mathrm{T} 2$ there was increase suggestive of maxillary protrusion, due to point A being directed downward and forward. This result was confirmed by a significant increase in the SNENA measure, with maxillary displacement downward and forward (Tables 1, 2 and 3), (Figures 2-4, 6 and 7). 
Although the ANL measurement did not decrease and measures 1NA and S'-ENA did not increase in a statistically significant way, these changes were observed in all patients, suggesting that the displacement of the upper incisors forward and consequently of the upper lip, since there is a direct relationship between them [11] (Tables 1, 2 and 3 Figures 6 and 7).

In all treated patients, greater orthopedic effects were observed than dental ones (Tables 1,2 and 3), because all were in a favorable stage of growth, called pre-peak stage of pubertal growth[14]. Better results are obtained when the facial mask treatment is performed at the beginning of the mixed dentition [5,14,18], corroborating our findings.

The linear measure S'-ENA did not increase significantly, statistically, when the two groups were evaluated simultaneously (Table 3). However, when assessed separately, it was observed that in group 1, the anterior maxillary displacement was more expressive (Tables 1 and 2) (Figures 6 and 7). It suggests that the RMT after RME has an orthopedic effect in the anterior sense greater than when performed simultaneously with the disjunction, corroborating the findings of other authors [3] when affirming that there is still no consensus on the benefits of concomitant association of RME with RMT. According to these authors [3], intense cellular activity has been observed in the sutures, originating from RME, and may provide more expressive results to this intervention.

The linear measure S'-A increased significantly (Tables 1,2,3), suggesting that orthopedic mechanics acted on the maxilla by moving it forward, without interfering with growth, since it is determined genetically.

There was an improvement in overjet, from negative to positive in all cases treated with incisor uncrossing, although it was not statistically significant. This fact was expected since the RMT was more expressive in the maxilla than in the dental positions.
However, the upper and lower labial posture with respect to the base of the nose and mentum improved significantly, represented by the S-LS and S-LI measurements, with a change from the concave profile to slightly convex, corroborating the findings of other authors $[10,13-15,18]$, when finding that it is a consequence of both maxillary protraction and obtaining a positive overjet (Tables 1, 2 and 3) (Figures 6 and 7).

The early treatment of skeletal Class III with facial mask makes it possible to minimize future surgical interventions and reestablish functions, rescuing the self-esteem, since it is a deviation that greatly affects aesthetics. However, it seems difficult to predict the stability of this therapy, since it will depend on the growth pattern of the posttreatment patient, but a prognosis can be made based on the initial morphological characteristics, that is, considering the maxillary or mandibular component that make up Class III $[15,16,18]$.

The authors believe that the long-term impact of this treatment does not present predictability, but may help establish a normal occlusion, minimizing the maxillomandibular discrepancy allowing a more harmonious growth and development of the average face of the individual. Corroborating other authors [15-21] early intervention has been indicated more frequently with the aim of eliminating primary etiological factors, since the intramembranous maxillary growth favors an orthopedic response, compared to the treatment of restriction of the mandibular growth avoiding that the malocclusion already installed aggravates with the growth.

It should be emphasized that Cordaso et al. [21] found in their research that facemask is effective correcting Class III malocclusion in the short term. The skeletal modifications induced by facemask are forward displacement of maxilla, backward displacement of mandible, clockwise rotation of the mandibular plane, and counterclockwise rotation of the maxillary plane. 
As posttreatment growth can not be determined previously, it is essential to overcorrection the horizontal overpass and maintain the containment for an appropriate period. This should be clarified to the parents and the patient from the outset so that they are properly informed and invited to cooperate with treatment and supervision after treatment $[1-7,14-16,18]$.

\section{CONCLUSION}

Class III malocclusion with maxillary deficiency treated with rapid maxillary disjunction and reverse traction with facial mask was effective in both groups, with maxillary protraction and shifting in the concave to slightly convex profile.

Knowing the dentoskeletal changes and all their consequences in the craniofacial structure is of fundamental importance for the efficacy of the therapy in the treatment of Pattern III Class III and maintenance of the stable results.

\section{REFERENCES}

1. Fontes JOL, Thiesen G. Estudo cefalométrico prospectivo dos efeitos da terapia de tração reversa da maxila associadaà mecânica intermaxilar. Dental Press J Orthod. 2011,16(6):38.e1-9.

2. Bezerra JO, Silva AM, Peixoto MGS, Tiago CM. Tratamento da má oclusão de classe III por meio de disjunção maxilar e tração reversa da maxila: relato de caso. J Odontol Facit. 2014,1(1):32-39.

3. Araújo EA, Araújo CV. Abordagem clínica não-cirúrgica no tratamento da má oclusão de Classe III. R Dental Press Ortodon Ortop Facial. 2008,13(6):128-157.

4. Perrone APR, Mucha JN. 0 tratamento da Classe III - revisão sistemática Parte I. Magnitude, direção e duração das forças na protração maxilar. RDental Press Ortodon Ortop Facial.2009, 14(5):109-117.

5. Oltramari PVP,Garib DG, Conti ACCF, Henriques JFC, Freitas MR. Tratamento ortopédico da classe III em padrões faciais distintos. R Dental Press Ortodon Ortop Facial. 2005,10(5):72-82
6. Gallão S, Martins LP,Faltin Jr K, Gandini Júnior LG, Pieri LV, Gaspar AMM, Bolin PDA. Diagnóstico e tratamento precoce da Classe III: relato de caso clínico.J Health Sci Inst. 2013,31(1): 104-108.

7. Weissheimer F,Brunetto AR, Petrelli E. Disjunção palatal e prostração maxilar: alterações cefalométricas pós-tratamento. J Bras Ortodon Ortop Facial.2003;8(44):111-121

8. Moscatiello VAM, Lederman H, Moscatiello RA, Faltin Jr K, Moscatiello RM. Maturação das vértebras cervicais e sua correlação com a idade óssea da mão e punho como indicadores no tratamento ortodôntico. Dental Press Ortodon Ortop Facial. 2008; 13(4):92-100.

9. Lara TS, BertozFA, Santos ECA, Bertoz APM. Morfologia das 3 e 4 vértebras cervicais representativa do surto de crescimento puberal. Dental Press Ortodon Ortop Facial. 2008;13(6):66-76.

10. Thiesen G, Fontes JOL, Zastrow MD, Lima MH, Nuernberg N. Tração reversa da maxila associadaà mecânica intermaxilar no tratamento precoce do Padrão III: relato de caso. Rev. Clin. Ortodon. Dental Press. 2009; 8(4):84-92

11. Vilella OV. Manual de Cefalometria. Revinter.2009; 3ed, Rio de Janeiro.218p.

12. Dahlberg G. Statistical methods for medical and biological students. London:Allen \& Unwin; 1940.

13. Antunes CF,Camarote EA, Quaggio ÂM, Bigliazzi R, Ortolani CLF, Faltin JrK. Alterações dentárias decorrentes da expansão rápida da maxila e máscara facial reversa. Braz Dent Sci. 2010; 13 (6):36-41.

14. Primo BT, Eidt SV, Gregianin JA, Primo NA, Junior IMF. Terapia da tração reversa maxilar com máscara facial de Petit - relato de caso. RF0, 2010; 15(2):171-176.

15. Rodrigues LRL, Baddredine FR, Cappellette Jr M, França NM. Protração maxilar associada à disjunção maxilar ortopédica. Rev. Clín. Ortodon. Dental Press.2007;6(3):48-56.

16. Freire AB, Nascimento LEAG, Lira ALS, Efeitos induzidos após uso de aparelhos para tração reversa da maxila: uma revisão de literatura. Dental Press J Orthod. 2012;17(4): 122-8.

17. Souza CC, Valdrighi HC, Santos JCB, Menezes CC, Belani AL, VedovelloSAS Associação entre a idade óssea determinada pelas vértebras cervicaise estágios de desenvolvimento de formação dentária. Orthod. Sci. Pract. 2017; 10(37):27-32.

18. Pithon MM, Oliveira MV,Bernarde LAA. Interceptação da maloclusão de Classe III Angle na dentição mista: relato de caso clinico. Revista Associação Paulista de Especialistas em Ortodontia - Ortopedia Facial.2003;1(4):44-52.

19. Goulart MS, Ladewig VM, Almeida-Pedrin RR, Conti ACCF,Cardoso MA, Palhano AO. Early treatment of pattern III class III with face mask therapy. Ortodontia SPO.2015; 48(6):521-5.

20. Fontes JOL, Thiesen G. Prospective cephalometric study of the effects of maxillary reverse traction therapy associated with intermaxillary mechanics. Dental Press J Orthod. 2011,16(6):38.e1-9.

\section{Ana de Lourdes Sá de Lira} (Corresponding address)

Universidade Estadual do Piauí. Faculdade de Odontologia Rua Senador Joaquim Pires 2076 - Ininga.

CEP: 64049-590. Teresina - PI - Brasil.

Date submitted: 2019 May 16

E-mail: anadelourdessl@hotmail.com 